\title{
Relationship of Knowledge, Skills, and Cadre's Guidance with The Cadre's Activeness in Family Nutrition Support at Puskesmas Barana North Belopa in 2017
}

\author{
Wahyu Hidayat ${ }^{1}$, Resty Ryadinency ${ }^{2}$, Jumraini ${ }^{2}$ \\ ${ }^{1}$ Ners Profession at Mega Buana Palopo College of Health Sciences \\ ${ }^{2}$ Public Health, Mega Buana Palopo College of Health Sciences \\ wahyu_hidayat_wahyu@yahoo.com \\ DOI: http://doi.org/10.29080/jhsp.v3i3S.289
}

\section{Keywords}

Cadre's Liveliness;

Knowledge;

Skill;

Cadre's Supervision.

\begin{abstract}
Posyandu cadres are community members who are willing, able and have time to organize Posyandu activities in a voluntary way. Factors associated with the liveliness of Posyandu are cadre's knowledge, skills and supervision. These factors can determine the activeness of community helath center cadres (Posyandu) to family nutrition support. This study was observational with cross-sectional design, the population in this study were all cadres in 9 units Posyandu in the work area of Puskesmas Barana North Belopa Luwu Regency. Sampling was total sampling, which were 45 respondents. Data collection used questionnaires. The data collected were then processed and analyzed using univariate and bivariate analysis chi-squre test using statistic program (SPSS) 20. The table was presented in a $2 \times 2$. An univariate analysis was to find frequency distribution, in which bivariate analysis showed a correlation between knowledge and cadre's liveliness in supporting family nutrition improvement $(p=, 000)$. There is a relationship between skill and cadre's liveliness in family nutrition support $(p=, 000)$, there is a relationship between cadre's guidance and cadre's activeness in family nutrition support $(p=, 014)$. There is a relationship of knowledge, skills, and cadre's guidance with the cadre's activeness in family nutrition support at Puskesmas Barana North Belopa in 2017.
\end{abstract}

\section{Introduction}

Posyandu cadres are members of the community who are willing, able, and have time to hold Posyandu activities on a regular basis. These activities are real activities that involve community participation in the efforts of health services from the community, which are carried out by health cadres who have received education and training from puskesmas (community health centers) regarding basic health services (1). More than 40,000 of the 67,000 villages in Indonesia, there are trained volunteers or cadres, are working to help their communities protect children's health. One result is that around 5 million mothers in Indonesia periodically weigh their children and help their growth. Cadres are chosen by the community to be trained and foster 10-15 families (2).

Based on weighing of toddlers in Posyandu, it was found as many as 26,518 malnourished children under five nationally. The case of malnutrition in question was determined based on the calculation of body weight according to Zscore toddlers' height <-3 standard deviations (very thin toddlers)(3). Whereas according to the results of Riskesdas 2013 the prevalence of very thin nutrition in infants was $5.3 \%$. If it is estimated for the target number of children under five (S) registered in the reporting Posyandu $(21,436,940)$, the estimated number of malnourished children (very thin) is around 1.1 million(4). This, the finding of cases of malnourished children under five is far from the estimated cases of malnutrition in the community. Therefore, efforts are needed to increase community participation in weighing their children because the coverage of under-fives has not reached three-quarters of the number of children under five registered in the Posyandu report. .

A total of 305 cadres attended the training in Luwu, but only around 226 or (74\%) are active cadres(5). Whereas in 2015 as many as 321 cadres who attended training were only about 229 or (71\%) are active cadres (6), and in 2016 as many as 301 cadres who participated in the training were only around 
215 or (71\%) are active cadres(7). Along with that, in 2014, there were 60 cadres of the Puskesmas Barana who participated in the training, only about 45 or (75\%) are active cadres (8). Whereas in 2015 as many as 50 cadres were trained by only 34 or (68\%) active cadres (9), and in 2016 as many as 45 cadres needed only around 30 or $(66.6 \%)$ active cadres $(10)$.

Based on the description above, considering the Posyandu cadre is also called the village health promoter and the cadre is aimed at the success of national development, specifically in the health sector, it is necessary to conduct research on factors related to the activeness of Posyandu cadres in the efforts to improve family nutrition at Puskesmas Barana, North Belopa in 2017.

\section{Methods}

A cross-sectional study was conducted among cadres in the Puskesmas Barana, North Balopa Luwu Regency. The total samples was 45 participants. The questionnaire consists of several questions submitted according to the variables that will be investigated. The cadre activeness variable consists of 2 questions, the knowledge variable consists of 15 multiple choice questions, the skill variable consists of 14 questions in the form of a checklist, and for the cadre coaching variable consists of 2 multiple-choice questions. The data collection instruments were tested and validated previously. The data were analyzed statistically by using SPPS. Meanwhile all variables were tested by chi-square (11).

\section{Results}

The relationship of knowledge with the activeness of posyandu cadres

Table 1. Knowledge Relationship with the Activeness of Posyandu Cadres in Family Nutrition Improvement Efforts

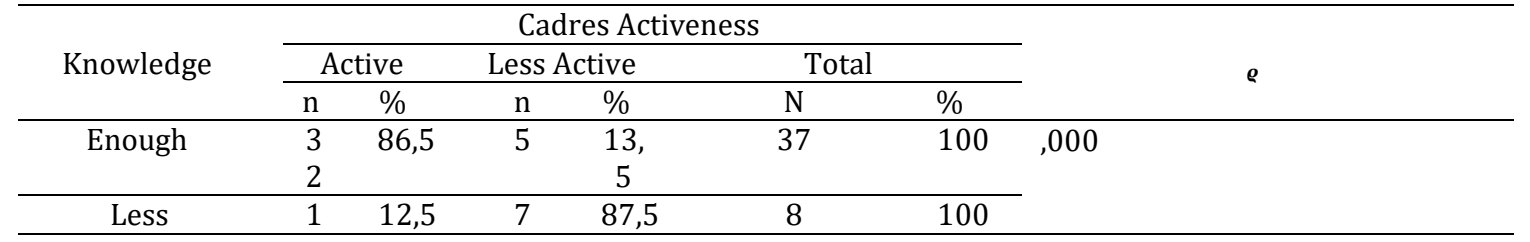

Sources: Primary Data, 2017

Based on Table 4.5, it is shown that of the 45 people respondents, who have sufficient knowledge with active cadres active as many as 32 people (86.5\%) and who have sufficient knowledge with active activists who are less active as many as 5 people $(13.5 \%)$. Whereas those who have less knowledge with active cadres active as many as 1 person (12.5\%) and who have less knowledge with active activists who are less active as many as 7 people (87.5\%). Based on the results of test chi-square, it is obtained $\mathrm{p}=$ value $0,000<$ value $\alpha=0,005$. This means Ha accepted that there is no relation between knowledge with the liveliness of health cadres in family nutrition improvement at Puskesmas Barana North Belopa Luwu Regency.

The relationship of skills with the activeness of posyandu cadres

Table 2. Relationships Skills with the Activeness of Posyandu Cadres in Family Nutrition Improvement Efforts

\begin{tabular}{cccccccc}
\hline & \multicolumn{6}{c}{ Cadres Activeness } & \multirow{2}{*}{ Total } \\
\cline { 2 - 8 } Skills & \multicolumn{2}{c}{ Active } & \multicolumn{2}{c}{ Less Active } & \multicolumn{2}{c}{} & \\
\cline { 2 - 8 } & $\mathrm{n}$ & $\%$ & $\mathrm{n}$ & $\%$ & $\mathrm{~N}$ & $\%$ & \multirow{2}{*}{000} \\
\hline Skilled & 32 & 88,9 & 4 & 11,1 & 36 & 100 \\
\hline Less Skilled & 1 & 11,1 & 8 & 88,9 & 9 & 100 & \\
\hline
\end{tabular}

Source: Primary Data, 2017

Based on Table 2, it is shown that of 45 people the number of respondents, who have skilled skills with active cadres active as many as 32 people (88.9\%) and who have skilled skills with active activists who are less active as many as 4 people (11.1\%). Whereas those who have less skilled skills with active cadres active as many as 1 person (11.1\%) and who have less skilled skills with active activists who are less active as many as 8 people (88.9\%). Based on the results of the test chi-square obtained the value of $p=0,000$ $<$ value of $\alpha=0,05$. This means that Ha is accepted, namely there is a skill relationship with the activeness of Posyandu cadres in efforts to improve family nutrition at Puskesmas Barana North Belopa Luwu Regency. 
Relationship between cadres guidance and activeness of posyandu cadres

Table 3. Relationship between Cadre Guidance and Posyandu Cadre Activeness in Family Nutrition Improvement Efforts

\begin{tabular}{cccccccc}
\hline & \multicolumn{7}{c}{ Cadres Guidance } \\
\multirow{2}{*}{ Guidance } & \multicolumn{2}{c}{ Active } & \multicolumn{2}{c}{ Less Active } & Total & \multirow{2}{*}{ e } \\
\cline { 2 - 8 } & $\mathbf{n}$ & $\mathbf{\%}$ & $\mathbf{n}$ & $\mathbf{\%}$ & $\mathbf{N}$ & $\mathbf{\%}$ & \multirow{2}{*}{$\mathbf{0 1 4}$} \\
\hline Good & 32 & 86,5 & 5 & 13,5 & 37 & 100 \\
\hline Poorly & 1 & 12,5 & 7 & 87,5 & 8 & 100 & \\
\hline
\end{tabular}

Source: Primary Data, 2017

Based on Table 3, shows that of the 45 respondents, who have good cadre guidance with active cadres activeness as many as 25 people (86.2\%) and who have good cadre guidance with active activities of less active cadres as many as 4 people (13.8\%). Whereas those who have poor cadre guidance with active cadres are 8 people (50\%) and who have poor cadre guidance with 8 active cadres active (50\%). Based on the results of the test chi-squre obtained the value of $p=0,014<$ value of $\alpha=0,05$. This means that Ha is accepted, namely there is a relationship of cadre development with the activeness of Posyandu cadres in the effort to improve family nutrition at Puskesmas Barana Kecamatan Belopa Utara Kabupaten Luwu.

\section{Discussion}

Based on Table 1, it is shown that from 45 people, the number of respondents who have sufficient knowledge with active cadres activeness as many as 32 people (86.5\%) and who have sufficient knowledge with active activists who are less active as many as 5 people (13.5\%). Whereas those who have less knowledge with active cadres active as many as 1 person (12.5\%) and who have less knowledge with active activists who are less active as many as 7 people (87.5\%).

Of the 45 respondents who had sufficient knowledge with active cadres active as many as are 32 respondents (86.5\%). This was because the knowledge and insight of posyandu cadres was enough so that cadres knew the duties and roles of a cadre in posyandu services compared to those who lack knowledge with activeness 7 less active cadres (87.5\%). This is because they do not know what they need to do in the posyandu service.

The statistical results of the chi-squre test obtained $p$-value $=000<\alpha$ value $=.05$, meaning that there is a relationship of knowledge with the activeness of Posyandu cadres in the effort to improve family nutrition at Puskesmas Barana Belopa Utara in 2017. This research is in line with research conducted by Harisman \& Dwinuryani stating that based on the results of statistical tests obtained there is influence of knowledge $(\mathrm{p}=.017)$ on the activeness of Posyandu cadres in Mulang Maya Village, South Kotabumi District, North Lampung Regency in 2012 (12).

In accordance with the research conducted by Tirayoh, Kandou, \& Abeng (2017) factors related to the activeness of Posyandu cadres in the work area of Kema Community Health Center, Kema Sub-district, North Minahasa Regency, stated that there was a relationship between knowledge and the activeness of Posyandu cadres in the Kema Health Center Kema District working area (13). North Minahasa Regency with a value of $p=.000<\alpha$ value $=0,05$ (14). Similar to the research conducted by Suyat \& Hasanah (2014) about factors related to cadre activeness in Posyandu activities at Palasari Health Center Subang District stated that there was a relationship of knowledge with cadre activeness in Posyandu activities, with a value of $p=.032$ (15). Likewise, the research conducted by Handika (2016) the activeness of Posyandu cadres stated that there was a relationship between the level of knowledge and skills and the activeness of cadres in running Toddler Posyandu in Pacalan Village, Plaosan Health Center with $p=036<\alpha, 05$ (16).

This research agrees with the theory of Syafrudin (2011) that cadre knowledge is one of the important factors in achieving the success of Posyandu activities, especially in efforts to improve nutrition (17). This cadre knowledge can be seen from all Posyandu implementation activities. The improvement of cadre knowledge needs to be carried out in accordance with the problems faced by the cadres so that the achievement of Posyandu activities is successful. In order to achieve the implementation of efforts to improve family nutrition, cadres need to improve insight, and brotherhood knowledge to uphold the realization of a healthy and prosperous family

The better of the cadre's knowledge about the importance of the cadre's role in efforts to improve family nutrition and community health services as well as the improvement of the quality of Posyandu services, the more active it is in providing Posyandu services especially in efforts to improve family nutrition, because with the knowledge of the posyandu cadre, the posyandu cadre know about the role of each cadre so that posyandu services are also getting better quality and indirectly community visits to posyandu will increase.

Based on Table 2, shows that of the 45 respondents, who have skilled skills with active cadres active as many as 32 people (88.9\%) and who have skilled skills with active activists who are less active as many as 4 people (11.1\%). Whereas those who have less skilled skills with active cadres active as many as 
1 respondent (11.1\%) and who have less skilled skills with active activists who are less active as many as 8 people (88.9\%). Of the 45 respondents according to the research results, cadres who have skilled skills with active activists are 32 people (88.9\%) higher which is than the percentage of less skilled cadres with $1(11.1 \%)$ active cadres, shows that cadres who have skilled skills are certainly more active than the less skilled cadres.

The statistical results of the chi-square test obtained $p=000<\alpha=.05$, that is, there is a skill relationship with the activeness of Posyandu cadres in the effort to improve family nutrition at Puskesmas Barana Belopa Utara in 2017. This research is in line with research conducted by Harisman \& Dwinuryani (2012) stating that the results of statistical tests found that there was a skill influence on the activeness of Posyandu cadres in Mulang Maya Village, South Kotabumi District, North Lampung Regency in 2012, with a value of $p=.025$ (18). In accordance with the research conducted by Tirayoh et al (2017) on factors related to the activeness of posyandu cadres in the Kema Health Center work area, Kema Sub-district, North Minahasa District, stated that there was a relationship between skills, coaching with the activeness of Posyandu cadres in the LangsaBaro District Health Center Langsa Baro Nagro Aceh Darussalam with a value of $\mathrm{p}=, 037$ [6].

This research is in line with the theory of Eny \& Sriati (2011) that in the implementation of Posyandu, it must be motivated by trained and skilled cadres to carry out routine activities at the posyandu and outside Posyandu open days for optimal coverage of nutrition programs[1]. Cadres as the spearhead of various posyandu activities are tasked as extension agents and community activists to carry out efforts to improve family nutrition need to improve cadre skills which include ways of weighing, reading the results of weighing, how to fill KMS and be able to interpret the results of weighing correctly, able to do true counseling to the family of toddlers, and improve cadre skills in managing posyandu, BinaKeluarga Toddler (BKB) and efforts to increase family income, counseling, elderly health, and adolescent reproductive health and food security in families. The lack of active posyandu cadres in posyandu services was caused by their lack of skill in service at posyandu while the results showed that the more skilled the posyandu cadres were in the preparation and implementation of activities during posyandu services, the more active the posyandu cadres were in providing services. Services especially in efforts to improve family nutrition.

Based on Table 3, it is shown that of the 45 respondents, who have good cadre guidance with active cadres active as many as 25 people (86.2\%) and who have good cadre development with 4 active cadres active $(13,8 \%)$. Whereas those who have poor cadre formation with active cadres are 8 people (50\%) and who have poor cadre guidance with 8 active cadres active (50\%).

Of the 45 respondents based on the results of the study found a higher percentage of cadres who have good cadre development with active activists as much as $86.2 \%$ compared to cadres who have poor cadre coaching with active cadres only $50 \%$ that indicate an active Posyandu cadres. Turned out that they had attended coaching at least once a year, so they knew the duties of a cadre and the steps in posyandu services especially in the effort to improve family nutrition.

The results of the chi-square test statistics obtained $p=014<\alpha=.05$, showing that is there is a cadre coaching relationship with the activeness of Posyandu cadres in the effort to improve family nutrition at Puskesmas Baranain 2017.

This research is supported by the research conducted by Tirayoh et al (2017) on factors related to the activeness of Posyandu cadres in the Kema Health Center working area, Kema Sub-district, North Minahasa District, stating that there is a relationship between training/cadre development and the activeness of Posyandu cadres at Langsa Health Center Baro District Langsa Baro Nagro Aceh Darussalam with $p=019$. In accordance with the research conducted by Roesli, Maramis, \&Kolibu, (2017), about the factors related to the activeness of Posyandu toddlers in the work area of PuskesmasTumpaan, Kabupaten Minahasa Selatan stated that there was a relationship between cadre guidance and Posyandu cadre activeness with $\mathrm{p}=0.008$.

The lack of guidance carried out by health workers to Posyandu cadres in the work area of North Barana Belopa Health Center causes the lack of active Posyandu cadres in Posyandu services. Because they do not understand the duties of a Posyandu cadre, especially in efforts to improve family nutrition while according to results. Research shows that the more frequent Posyandu cadres follow the development of Posyandu cadres, at least 2 times a year, the more active the Posyandu cadres are in providing Posyandu services.

\section{Conclusion and Suggestion}

Knowledge, skills, and cadre guidance provide an overview of the close relationship with the activeness of Posyandu cadres in efforts to improve family nutrition at Puskesmas Barana North Belopa District in 2017.

The authors would like to thank the head of the district health office of Luwu, the head of the PKM Barana North Belopa District, and the Barana PKM cadres who helped during this study. 


\section{References}

1. Eny R,, Y Sriati. Asuhan Kebidanan Komunitas. Yogyakarta: Nuha Medika; 2011.

2. Syafrudin, Ayi D., D., Delmaifanis. Himpunan Penyuluhan Kesehatan. Jakarta: Trans Info Medika; 2011.

3. Kementrian Kesehatan Republik Indonesia. Strategi Peningkatan Penimbangan Balita. Jakarta: Kementrian Kesehatan Republik Indonesia; 2014.

4. Kementrian Kesehatan Republik Indonesia. Kader Posyandu Menuju Keluarga Sadar Gizi. Jakarta: Kementrian Kesehatan Republik Indonesia; 2013.

5. Dinas Kesehatan Kabupaten Luwu. Profil Dinas Kesehatan Kabupaten Luwu. Luwu: Dinas Kesehatan Kabupaten Luwu; 2014.

6. Dinas Kesehatan Kabupaten Luwu. Profil Dinas Kesehatan Kabupaten Luwu. Luwu: Dinas Kesehatan Kabupaten Luwu; 2015.

7. Dinas Kesehatan Kabupaten Luwu. Profil Dinas Kesehatan Kabupaten Luwu. Luwu: Dinas Kesehatan Kabupaten Luwu; 2016.

8. Puskesmas Barana. Profil Puskesmas Barana Kecamatan Belopa Utara Kabupaten Luwu. Luwu: Puskesmas Barana; 2014.

9. Puskesmas Barana. Profil Puskesmas Barana Kecamatan Belopa Utara Kabupaten Luwu. Luwu: Puskesmas Barana; 2015.

10. Puskesmas Barana. Profil Puskesmas Barana Kecamatan Belopa Utara Kabupaten Luwu. Luwu: Puskesmas Barana; 2016.

11. Azis A. Metode Penelitian Kebidanan danTehnik Analisis Data. Jakarta: Salemba Medika; 2014.

12. Harisman, H.,, Dwinuryani, D. Faktor yang terhadap keaktifan kader Posyandu di Desa Mulang Maya Kecamatan Kotabumi Selatan Kabupaten Lampung Utara Tahun 2012. Jurnal Dunia Kesmas. 2012;1(4):1-8.

13. Tirayoh, N., Kandou, G., D., Abeng, T., D., E. Faktor-Faktor Yang Berhubungan dengan Keaktifan Kader Pos Pelayanan Terpadu (Posyandu) Di Wilayah Kerja Puskesmas Kema Kecamatan Kema Kabupaten Minahasa Utara. Community Health. 2017;2(1):110.

14. Roesli, A., M., W., Maramis, F., R., R.,, Kolibu, F., K. Faktor-Faktor yang berhubungan dengan Keaktifan Kader Posyandu Balita Di Wilayah Kerja Puskesmas Tumpaan Kabupaten Minahasa Selatan. JurnalIKMAS 1 (7), 1-9. 2017;1(7):1-9.

15. Suhat, Hasanah, R. Faktor-Faktor yang Berhubungan dengan Keaktifan Kader dalam Kegiatan Posyandu (Studi di Puskesmas Palasari Kabupaten Subang)\& Hasanah, R. Jurnal Kesehatan Masyarakat. 2014;10(1):73-9.

16. Handika, F., F. Hubungan Tingkat Pengetahuan dengan Keaktifan Kader dalam Menjalankan Posyandu Balita Di Desa Pacalan Wilayah Kerja Puskesmas Plaosan. 2016. Skripsi Sarjana. Fakultas Ilmu Kesehatan Masyarakat. Universitas Muhammadiyah Surakarta.

17. Syafrudin, Ayi D., D.,, Delmaifanis. Himpunan Penyuluhan Kesehatan. Jakarta: Trans Info Medika; 2011. 